\title{
A Relação Família-Escola sob a ótica de Professores e Pais de crianças que frequentam o Ensino Fundamental
}

\author{
Lisiane Alvim Saraiva* \\ Adriana Wagner**
}

\section{Resumo}

Embora já estejam comprovados os benefícios da proximidade entre a Família e a Escola, constata-se que ainda existem muitos empecilhos para que esta relação seja eficaz. A escola parece ter dificuldades em compreender a realidade vivida por seus alunos e famílias e a assimetria nessa relação tende a perpetuar as dificuldades de construir uma aliança eficaz que favoreça o envolvimento do aluno no espaço acadêmico. Frente a essa realidade, o objetivo do presente trabalho é apresentar a perspectiva da escola e da família sobre as vicissitudes dessa relação a partir dos depoimentos de pais e professores de Ensino Fundamental. Realizou-se dois grupos focais: um com professores de Ensino Fundamental (dez participantes) e outro com pais de alunos (sete participantes) que frequentam a mesma etapa de escolarização. A partir da Análise de Conteúdo, as informações do grupo focal com os docentes configuraram os seguintes temas: Demandas das famílias que aparecem na prática docente; Situações que demandam interação com as famílias; Percepção do professor sobre a família e sobre seu papel. A análise do grupo de pais culminou nos seguintes temas: $\mathrm{O}$ envolvimento da família com a escola dos filhos; A comunicação com a escola; Dificuldades Percebidas na Relação Famíla-Escola, Mercantilização da Educação. As conclusões remetem a uma realidade perfilada por fronteiras difusas entre família e escola, revelando dificuldades que obstruem essa relação e convergem para um jogo de culpabilidades mútuas. Discute-se a possibilidade de otimização dessa relação a partir de estratégias conjuntas sistemáticas que contemplem docentes e pais em suas reivindicações. Desde essa perspectiva, retoma-se a importância de desenvolver a tarefa educativa de forma conjunta, tendo sempre o aluno como foco e prioridadenesse processo. Palavras-chave: Relação Família-Escola. Ensino Fundamental. Educação.

Beneficiário de auxílio financeiro da CAPES Brasil; Bolsista CAPES de doutorado/UFRGS. E-mail: lisianesaraiva@hotmail.com

* Beneficiário de auxílio financeiro da CAPES Brasil; Bolsista produtividade CNPq. E-mail : adrianawagner. ufrgs@hotmail.com 


\section{Introdução}

A Família e a Escola são instituições que compartilham a tarefa de preparar e encaminhar os sujeitos para a vida nos seus mais diversos aspectos. Até o início do século XX, a educação das crianças se dava fundamentalmente sob a tutela da família, que controlava o aprendizado que ocorria em casa. Uma separação mais acentuada entre os papéis da escola e da família passou a acontecer a partir de meados do século $\mathrm{XX}$, quando a escola foi assumindo a responsabilidade pelo desenvolvimento de conteúdos formais e à família cabia seguir zelando pela educação moral, cultural e religiosa de suas crianças (VILA, 2003; HILL; TAYLOR, 2004). Sendo assim, atualmente, considera-se que a família e escola assumem responsabilidades complementares no que diz respeito à educação das crianças e jovens.

Estudos atuais apontam que uma boa parceria entre família e escola tende a ser fator preditor de saúde, visto que melhora o processo de aprendizagem, afeta positivamente os resultados acadêmicos. Previne igualmente problemas de comportamento, de frequência nas aulas, abandono escolar e estimula o seguimento dos estudos em nível superior (CAVALCANTE, 1998; BHERING; SIRAJ-BLATCHFORD, 1999; XU, 2002; POLONIA; DESSEN, 2005, KOUTROUBAetal.,2009;EPSTEIN, 2011). Frente aessa perspectiva, o presente estudo teve por objetivo conhecer a perspectiva de professores e pais de crianças do Ensino Fundamental a respeito das relações que vivenciam na interação família-escola.

A literatura referente à temática, produzida no Brasil, revela que a relação família-escola tem sido discutida, prioritariamente, a partir de dois enfoques: psicológico e sociológico (OLIVEIRA; MARINHO-ARAÚJO, 2010). O enfoque sociológico considera os determinantes ambientais e culturais e denuncia conflitos entre a educação e a classe social, entre os objetivos da escola e a organização das famílias. Na opinião de Lewis e Forman (2002), grande parte da literatura concentra-se em explicar e discutir de que forma a classe social dos pais afeta ou não o seu envolvimento com a escola. Características demográficas, status socioeconômico, etnia e background cultural são tidos como fatores associados ao envolvimento parental nas escolas (HILL; TAYLOR, 2004). Nesse sentido, as famílias que destoam do modelo almejado pela escola são consideradas responsáveis pelas disparidades escolares. Na visão das escolas, as famílias deveriam adotar as mesmas estratégias de socialização das crianças e jovens por elas utilizadas. Assim, quando os resultados são insatisfatórios e deficitários, ou se existem conflitos entre o currículo escolar e a educação doméstica, é sinal de que há problemas. Nessa perspectiva, a relação famíliaescola, portanto, depende basicamente do consenso entre filosofia educativa doméstica 
e currículo escolar (CARVALHO, 2004). A preocupação da escola passa a ser, então, as estratégias de socialização que as famílias utilizam. Com isso, a escola amplia seu leque de ação com a intenção de promover educação para as famílias tidas como "desestruturadas" e inábeis para educar seus filhos (OLIVEIRA; MARINHO-ARAÚJO, 2010). De acordo com Garbó (2013), o termo "desestruturado" traz uma conotação negativa para fazer referência àqueles grupos que não respondem ao modelo tradicional de família (pai, mãe e filhos) e que são desvalorizados pelo contexto educativo, embora haja nesses grupos adultos responsáveis que assumiram a educação e cuidados das crianças.

A partir desses pressupostos, os professores acabam pautando suas expectativas e entendimento das famílias em função da classe social da comunidade que atendem (LEWIS; FORMAN, 2002). Sendo assim, parece haver preferência por aqueles pais de classe média que possuem competência científica semelhante à sua, são mais esclarecidos, estão atentos à criança e conhecem a importância do processo de escolarização (VILLAS-BOAS, s.d). Em contrapartida, existe, também, uma falsa crença por parte dos professores de que os pais provenientes de nível socioeconômico menos favorecido não estão preocupados com seus filhos, adotando postura negligente e pouco participativa. Também pensam que estes não tem nada a contribuir para o currículo escolar, por não terem formação educacional destacada, sendo que sua participação deveria centrar-se em comparecer às reuniões e entregas de boletins (CAVALCANTE, 1998; POLONIA; DESSEN, 2005; RIBEIRO; ANDRADE, 2006).

Hill e Taylor (2004) e Lewis e Forman (2002) discutem que, de fato, os professores que provêm de contextos culturais diferentes dos seus alunos, são menos propensos a conhecer esses sujeitos e suas famílias se comparados àqueles que provém de contextos culturais semelhantes aos das famílias que atendem na escola. Além disso, as diferenças culturais entre professores e famílias fazem com que os primeiros acreditem que os alunos e pais sejam desinteressados ou não envolvidos como deveriam na escolarização dos seus filhos.

O enfoque psicológico, mencionado por Oliveira e Marinho-Araújo (2010), remete à crença de que o bom desempenho do aluno decorre de uma "boa" dinâmica familiar. Assim, esse enfoque considera prioritariamente os determinantes psicológicos presentes na estrutura familiar como os responsáveis pelas consonâncias e dissonâncias entre objetivos e valores nas duas instituições. Tais determinantes dizem respeito ao funcionamento familiar no que se refere à capacidade das famílias em serem flexíveis para lidar com as demandas do dia a dia, apresentarem proximidade afetiva e capacidade de comunicação 
profunda entre seus membros. A interação entre estes fatores caracterizam a dinâmica familiar a qual se expressará em maiores ou menores níveis de funcionalidade na relação família-escola (WAGNER; TRONCO; ARMANI, 2011). Entretanto, as concepções de senso comum, que se podem observar no discurso de professores e educadores, tendem a reduzir dicotomicamente as relações familiares em normais e patológicas, e, dessa forma, presumem resultados no desempenho escolar das crianças. Nesse sentido, a família tem estado por trás do sucesso escolar de seu filho assim como também tem sido culpada pelo fracasso. (CARVALHO, 2000).

A relação família-escola fica, portanto, marcada por culpas e não responsabilização compartilhada. A escola tende a apontar a falta de instrumentalização das famílias para a ação educacional (OLIVEIRA; MARINHO-ARAÚJO, 2010), pois persiste com a crença de que a família é omissa na educação dos filhos (SILVEIRA, 2011). Corroborando com tais ideias Wagner, Sarriera e Casas (2009) realizaram um estudo com o objetivo de examinar as percepções de pais e professores a respeito do grau de satisfação que tinham alternadamente uns dos outros, isto é, os pais com relação à escola e os professores com relação às famílias. Os resultados apontaram que os professores se mostraram bastantes críticos na avaliação do desempenho das famílias de seus alunos quanto à orientação que proporcionavam aos filhos, considerando temas como: educação alimentícia, educação sexual, educação cívica, educação na solidariedade e direitos humanos. Avaliaram, portanto, as tarefas educativas dos pais de maneira muito inferior do que avaliaram sua própria atividade como professores. Os pais, por sua vez, declararam que estavam bastante ou totalmente satisfeitos com relação à adequação da educação proporcionada pela escola aos seus filhos. Os autores revelam a existência de um descompasso das expectativas entre estes dois contextos de aprendizagem como um dos fatores da pouca valorização da família desde o espaço escolar.

De fato, por parte dos professores, algumas barreiras são identificadas para o estabelecimento de uma boa relação, tais como a apatia dos pais no que tange aos assuntos escolares e a sua própria limitação de tempo para contatar com a família(CAVALCANTE, 1998). Nessa dinâmica de interação, os encontros entre família e escola tendem a ocorrer, na maioria das vezes, devido a problemas comportamentais - situações nas quais a família é considerada como ineficiente para transmitir adequadas concepções de mundo e valores às crianças (RIBEIRO; ANDRADE, 2006). Essa perspectiva também aparece em outras realidades. Villas-Boas (s.d.), por exemplo, refere que em inúmeros estudos com professores portugueses estes apresentaram uma imagem negativa do papel parental, conforme é exercido nos dias de hoje. Mencionaram que os muitos problemas que os 
alunos apresentam têm origem no ambiente familiar, em função do desinteresse dos pais, da falta de apoio e valorização dos deveres escolares, da não imposição de regras, do desinteresse e ausência de envolvimento. Para esses profissionais, os pais deixam os filhos entregues a si próprios e encaram a escola como um depósito de crianças.

Por parte da família, no entanto, há alguns fatores inibitórios de participação, os quais podem incluir desde a sua baixa autoestima, alienação e desconfiança, até a desvalorização de seus recursos, a partir do momento em que percebem a escola de forma idealizada, como detentora do saber formal (CAVALCANTE, 1998; BHERING; DENEZ, 2002; DITRANO; SILVERSTEIN, 2006; RIBEIRO; ANDRADE, 2006; VYVERMAN; VETTENBURG, 2009). Outro obstáculo à participação e engajamento é a crença de alguns pais de que seu envolvimento poderia prejudicar a independência e autonomia dos filhos (BHERING; SIRAJ-BLATCHFORD, 1999; XU, 2002). Também alguns pais, cuja própria experiência escolar não foi bem sucedida, podem acabar transmitindo estas concepções negativas aos filhos, adotando uma postura distante e desconfiada frente a escola, sentindo-se à margem e alienados quando confrontados com a autoridade escolar (LEWIS; FORMAN, 2002). Além disso, as barreiras culturais podem dificultar tal aproximação, especialmente se a escola não considera a presença dos pais como fator importante no processo educativo (POLONIA; DESSEN, 2005; RIBEIRO;ANDRADE, 2006). Lewis e Forman (2002) também ressaltam que aspectos financeiros podem ser considerados um empecilho à participação, na medida em que, para alguns pais, custa caro a locomoção até a escola e seus trabalhos tem horários rígidos que não permitem que se retirem para atender a algum chamado da escola.

Percebe-se, assim, que, embora grande parte da literatura e das pesquisas apontem para os benefícios da relação Família-Escola e ressaltem que contatos pobres entre esses dois espaços acabam reverberando em prejuízo às crianças (SANDERS, EPSTEIN; CONNORS-TADROS, 1999), parece haver muitos empecilhos para que esta relação transcorra de forma eficaz. A exemplo disso, estudo realizado por Ribeiro e Andrade (2006) em uma escola pública do interior do estado de São Paulo, teve por objetivo compreender a relação entre família e escola a partir da perspectiva dos pais. Entrevistaram 22 responsáveis por alunos de $3^{\mathrm{a}} \mathrm{e} 4^{\mathrm{a}}$ séries do Ensino Fundamental (através de entrevista semi-estruturada) e abordaram os seguintes tópicos: a escola, a professora e a escolaridade. A partir da técnica de análise de conteúdo das informações, observaram que existe grande assimetria na relação família-escola, sendo que o conhecimento propagado pela escola é visto pelos pais como sendo superior ao seu, o que os leva a pensar que não estão aptos e sequer possuem requisitos para tornar seus questionamentos legítimos. Assim, muitas 
vezes, se colocam de forma submissa e não questionadora, ainda que percebam os descompassos entre as exigências da escola e sua realidade. Também quando os filhos apresentam dificuldades de aprendizagem ou de comportamento, sentem que a pressão da escola aumenta muito, a ponto de gerar evasão escolar. Especialmente no que tange ao fracasso escolar, os pais acabam assimilando o discurso da escola de que a dificuldade é exclusiva do aluno/filho, gerando no sujeito, com dificuldades, um forte sentimento de culpa. Assim, é muito comum que as representações e crenças dos pais sobre a explicação para as dificuldades do filho demonstrem que eles concordam com a escola. A escola, por sua vez, se relaciona com as famílias de forma a exigir delas complementaridade com relação às suas expectativas, atribuindo aos alunos a responsabilidade por suas próprias dificuldades.

Não parece, portanto, haver um movimento da escola no sentido de compreender a realidade vivida por seus alunos e famílias. A assimetria nessa relação tende a perpetuar as dificuldades de construir uma aliança eficaz com a família a fim de favorecer melhor envolvimento do aluno no espaço acadêmico. Frente a essa realidade que se tem retroalimentado, passaremos a apresentar a perspectiva da escola e da família sobre as vicissitudes dessa relação a partir dos depoimentos de pais e professores de Ensino Fundamental.

\section{Método}

Este é um estudo de caráter qualitativo exploratório, realizado a partir da técnica do Grupo Focal (MORGAN, 1988) com um grupo de professores e um grupo de pais de crianças que frequentavam a primeira etapa do Ensino Fundamental, os quais foram contatados através de telefonemas e emails, onde lhes foi feito o convite formal. A amostra ocorreu, assim, por conveniência, mediante indicações. A cada um dos participantes foram explicados os objetivos da pesquisa, bem como os aspectos de confidencialidade, anonimato e liberdade de desistência de participação a qualquer momento. Também foi averiguada a disponibilidade do participante para comparecer ao grupo em data, local e horário prédefinidos.

\subsection{Participantes}

O grupo de professores contou com a participação de dez docentes das redes pública e privada de escolas de Porto Alegre. Quatro delas trabalhavam na rede particular exclusivamente, cinco, na rede pública no momento do grupo e uma, na rede pública e particular simultaneamente. Entretanto, quase todas as 
participantes já haviam tido experiência com a rede pública e privada em algum momento de suas carreiras. As idades das participantes variaram dos 26 aos 53 anos, todas possuíam curso superior e o tempo de formadas variava de quatro a 24 anos. Aproximadamente metade do grupo trabalhava cerca de 20 horas semanais, enquanto a outra metade trabalhava de 40 a 44 horas.

Tabela 1 - Descrição dos participantes do GF - Professores

\begin{tabular}{|c|c|c|c|c|c|c|c|c|}
\hline Nome & Idade & Formação & $\begin{array}{l}\text { Tempo de } \\
\text { formada }\end{array}$ & $\begin{array}{c}\text { Tempo } \\
\text { no Ens. } \\
\text { Fund. }\end{array}$ & $\begin{array}{l}\text { Rede } \\
\text { Atual }\end{array}$ & $\begin{array}{c}\text { Expe- } \\
\text { riência } \\
\text { na outra } \\
\text { Rede }\end{array}$ & $\begin{array}{c}\text { Tempo } \\
\text { de tra- } \\
\text { balho na } \\
\text { escola } \\
\text { atual }\end{array}$ & $\begin{array}{c}\text { Horas } \\
\text { de tra- } \\
\text { balho } \\
\text { sema- } \\
\text { nal } \\
\end{array}$ \\
\hline Clarissa & 37 & Psicologia & $\begin{array}{c}\text { 12anos } \\
\text { Psicologia } \\
21 \text { anos } \\
\text { Magistério }\end{array}$ & 20 anos & Particular & $\begin{array}{l}\text { Sim está- } \\
\text { gio }\end{array}$ & 20 anos & $23 \mathrm{hs}$ \\
\hline $\begin{array}{c}\text { Carolina } \\
\mathbf{M} .\end{array}$ & 29 & $\begin{array}{l}\text { Pedagogia } \\
\text { (supervi- } \\
\text { são) }\end{array}$ & 5 anos & $31 / 2$ anos & Pública & Sim & $31 / 2$ anos & $20 \mathrm{hs}$ \\
\hline Cláudia P. & 45 & $\begin{array}{l}\text { Pedagogia } \\
\text { (séries } \\
\text { iniciais e } \\
\text { supervi- } \\
\text { são) }\end{array}$ & 21 anos & 25 anos & Particular & Sim & 6 anos & $\begin{array}{c}241 / 2 \\
\text { hs }\end{array}$ \\
\hline Elisa & 37 & $\begin{array}{l}\text { Pedaogia } \\
\text { (séries } \\
\text { iniciais3 1/2 } \\
\text { anos) }^{*}\end{array}$ & 6 anos & 6 anos & Particular & Não & 5 anos & $\begin{array}{c}24 \frac{1}{1} 2 \\
\text { hs }\end{array}$ \\
\hline Gisele & 26 & Superior & 3 anos & $\begin{array}{l}1 \mathrm{sem} \\
\text { (estágio) }\end{array}$ & - & - & - & - \\
\hline Juliana & 28 & Pedagogia & 4 anos & 4 anos & $\begin{array}{l}\text { Pública e } \\
\text { Particular }\end{array}$ & - & $\begin{array}{l}\text { Particu- } \\
\text { lar: } 31 / 2 \\
\text { anos } \\
\text { Pública: } \\
2 \text { anos }\end{array}$ & $44 \mathrm{hs}$ \\
\hline Joana R. & 43 & $\begin{array}{l}\text { Pedago- } \\
\text { gia* }^{*}\end{array}$ & 6 anos & 7 anos & Pública & Sim & 5 meses & $40 \mathrm{hs}$ \\
\hline $\begin{array}{c}\text { Maria } \\
\text { Antônia }\end{array}$ & 53 & Pedagogia & 3 anos & 5 anos & Pública & Não & 5 anos & 40hs \\
\hline Mariana & 41 & $\begin{array}{l}\text { Licencia- } \\
\text { tura Mate- } \\
\text { mática }\end{array}$ & 24 anos & 26 anos & Pública & Sim & 2 anos & $20 \mathrm{hs}$ \\
\hline
\end{tabular}

Fonte: Os autores, 2013.

*Nomes das participantes foram trocados para preservar sua identidade

** Uma das participantes chegou um pouco atrasada no grupo, após o preenchimento da ficha com dados sociodemográficos, por isso seus dados não constam na tabela acima. 
O grupo focal com os pais contou com a participação de sete mães, com idades que variavam entre 36 e 49 anos e cujos filhos estavam no Ensino Fundamental de escolas públicas ou privadas de Porto Alegre. Seis mães eram casadas e uma, solteira. Os filhos passavam de quatro a cinco horas na escola, o equivalente a um turno diário. Muitos estão na mesma escola há mais de quatro anos, conforme mostra a Tabela abaixo.

Tabela 2 - Descrição dos participantes do GF - Pais

\begin{tabular}{|c|c|c|c|c|c|c|c|}
\hline Nome & Idade & $\begin{array}{c}\text { Estado } \\
\text { Civil }\end{array}$ & $\begin{array}{c}\text { Núme- } \\
\text { ro de } \\
\text { Filhos }\end{array}$ & $\begin{array}{l}\text { Profissão/Ocu- } \\
\text { pação }\end{array}$ & $\begin{array}{c}\text { Escola } \\
\text { pública } \\
\text { ou parti- } \\
\text { cular }\end{array}$ & $\begin{array}{l}\text { Tempo } \\
\text { que } \\
\text { está na } \\
\text { escola }\end{array}$ & $\begin{array}{l}\text { Horas } \\
\text { por dia }\end{array}$ \\
\hline $\begin{array}{l}\text { Ana } \\
\text { Maria }\end{array}$ & $\begin{array}{c}39 \\
\text { anos }\end{array}$ & Solteira & 1 & Professora & Particular & 2 anos & 5 horas \\
\hline Aline & $\begin{array}{c}45 \\
\text { anos }\end{array}$ & Casada & 1 & Empresária & Particular & 5 anos & $\begin{array}{c}4 \frac{1 / 2}{1 / 2} \\
\text { horas }\end{array}$ \\
\hline Cecília & $\begin{array}{c}41 \\
\text { anos }\end{array}$ & Casada & 2 & $\begin{array}{l}\text { Bacharel em } \\
\text { Informática }\end{array}$ & Particular & 6 anos & 5 horas \\
\hline Denise & $\begin{array}{c}37 \\
\text { anos }\end{array}$ & Casada & 2 & $\begin{array}{c}\text { Relações Pú- } \\
\text { blicas }\end{array}$ & Particular & 4 anos & 5 horas \\
\hline $\begin{array}{l}\text { Débora } \\
\text { C. }\end{array}$ & $\begin{array}{c}41 \\
\text { anos }\end{array}$ & Casada & 2 & Do Lar & $\begin{array}{l}\text { Pública } \\
\text { Federal }\end{array}$ & 5 anos & $\begin{array}{c}4 \text { hs e } 8 \\
\text { hs (dois } \\
\text { dias da } \\
\text { semana) }\end{array}$ \\
\hline $\begin{array}{l}\text { Eduar- } \\
\text { da }\end{array}$ & $\begin{array}{c}49 \\
\text { anos }\end{array}$ & Casada & 2 & $\begin{array}{l}\text { Trabalha em } \\
\text { Confecção }\end{array}$ & $\begin{array}{l}\text { Pública } \\
\text { Estadual }\end{array}$ & 5 anos & 4 horas \\
\hline Paula & $\begin{array}{c}36 \\
\text { anos }\end{array}$ & Casada & 2 & Psicóloga & Particular & 5 anos & 4 horas \\
\hline
\end{tabular}

Fonte: Os autores, 2013.

*Nomes das participantes foram trocados para preservar sua identidade

\section{Instrumentos e Procedimentos}

Os grupos focais tiveram caráter exploratório (GONDIN, 2003), para poder identificar necessidades, expectativas, promover insights e possibilitar o debate e a troca de experiências entre os participantes. A elaboração de um 
roteiro prévio a cada grupo (MORGAN, 1988), teve por objetivo fornecer um input ao debate, propondo questões abertas a serem pensadas em conjunto. Ambos os roteiros abordaram a temática da relação família-escola de forma a conhecer como cada grupo de participantes entendia, percebia e vivenciava esta relação, assim como também investigar as demandas da família que aparecem na prática docente dos professores e a maneira como as famílias recebem as demandas da escola, com as quais têm de lidar.

O conjunto de opiniões foi gravado em áudio e vídeo e juntamente com um questionário de dados sociodemográficos, que foi preenchido pelos docentes e pais antes do início dos grupos, constituíram o corpo efetivo das informações (DELGADO; GUTIÉRREZ, 1995) a partir do qual se realizou a Análise de Conteúdo. Esse estudo contou com aprovação do Comitê de Ética em Pesquisa do Instituto de Psicologia da Universidade Federal do Rio Grande do Sul, e atendeu a todos os preceitos metodológicos e éticos estabelecidos em lei.

\section{Análise de Dados}

As informações foram analisadas a partir dos eixos temáticos que surgiram na condução da discussão dos grupos com a utilização da técnica da Análise de Conteúdo (OLABUÉNAGA, 1999). A análise partiu, portanto, do estabelecimento de unidades temáticas de relevância extraídas do corpo do texto a partir dos roteiros temáticos preestabelecidos. No grupo focal com os docentes, abordaram-se os seguintes temas: Demandas das famílias que aparecem na prática docente; Situações que demandam interação com as famílias; Percepção do professor sobre a família e sobre seu papel. O grupo focal com mães abordou os seguintes temas: $O$ envolvimento da família com a escola dos filhos; A comunicação com a escola; Dificuldades Percebidas na Relação Famíla-Escola, Mercantilização da Educação.

\section{Resultados}

A análise dos grupos focais permitiu verificar que a ótica dos docentes sobre as famílias pode ser entendida a partir de três grandes temas, conforme esquema abaixo: 
Figura 1 - Temas que emergiram do Grupo de Professores

\section{Ótica dos Professores sobre as Famílias}
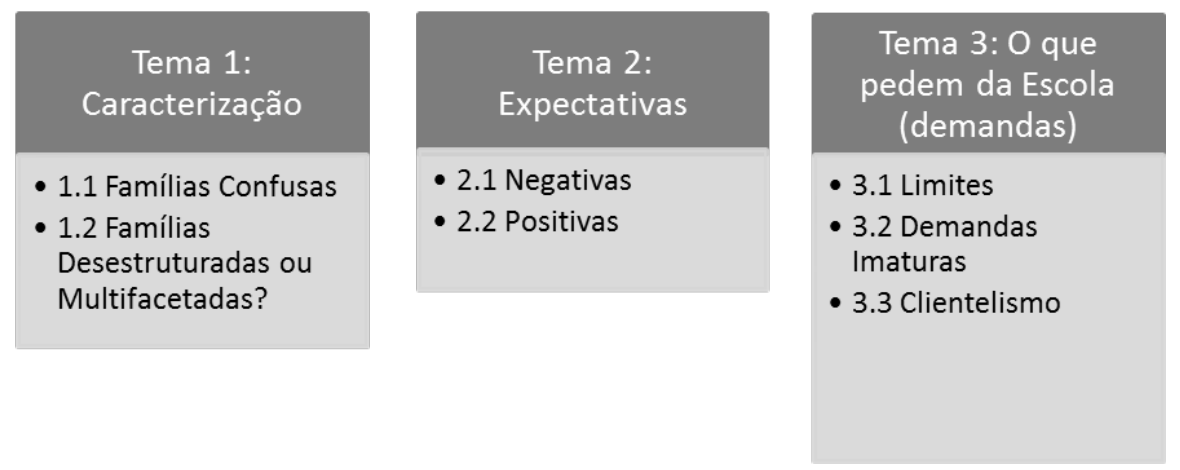

Fonte: Os autores, 2013.

A percepção dos pais acerca do tipo de relação estabelecida com as escolas de seus filhos também permitiu a classificação em quatro grandes temas, conforme o esquema a seguir:

Figura 2 - Temas que emergiram do grupo de Pais

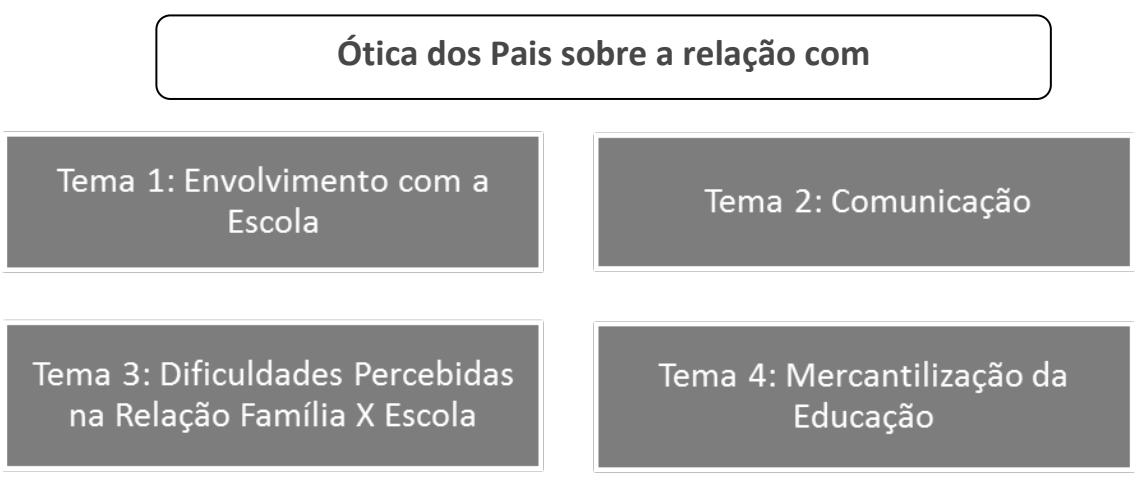

Fonte: Os autores, 2013. 


\section{Professoras}

\section{TEMA 1: Caracterização}

Neste tema, agrupam-se todas as opiniões e percepções presentes nas falas das professoras (como foi explicitado acima, eram todas do sexo feminino) sobre a forma como caracterizam e concebem as famílias em sua estrutura e organização. Aparece uma sensação de que as famílias estão "perdidas" por não saberem como lidar com seus filhos ou que são "desestruturadas", por não seguirem um padrão tradicional de configuração (pai, mãe e filhos).

\subsection{Famílias "confusas"}

As professoras participantes mencionaram um sentimento comum de que as famílias estão muito perdidas e confusas atualmente e que, por vezes, os pais burlam regras por inocência, por não saberem lidar com seus filhos. Mencionaram que se os profissionais que trabalham nas escolas não estiverem agindo de forma coerente e coesa, acabam também ficando confusos a partir do contato com estas famílias. Nas palavras de C. "eu vejo assim, as famílias muito confusas, atrapalhadas, não sabem como ajudar. Não ajudam o filho a crescer, têm dificuldades em aceitar as orientações da escola porque demanda trabalho!". As docentes, assim, acabam criticando a forma como as famílias educam seus filhos e consideram que os pais não estão seguros no exercício de sua função, além de constatarem que falta confiança da família na escola, conforme ilustra a fala: "acho que não existe escola de pais né... não acho que a escola seja a detentora desse saber também, mas acho que muitas vezes falta essa sintonia, de 'colocou seu filho nessa escola, então acredita nela...'!" (C.).

\subsection{Famílias Desestruturadas ou Multifacetadas?}

A ideia de que as famílias com as quais se enfrentam são multifacetadas, aparece na definição de famílias "desestruturadas", com muitos filhos, de múltiplos pais sem que haja clareza de quem é (são) o(s) responsável(is) pela prole. Esse fenômeno é descrito, especialmente, quando se referem às famílias de baixa renda. Nas palavras de E.: "A família é desestruturada hoje... é a mãe com cinco filhos, cada um de um pai diferente e esses pais não estão nem aí para as crianças". Revelam que nesses núcleos há diversos problemas e crianças que provêm destas organizações familiares estão mais propícias ao envolvimento em situações mais graves, tais como o uso de drogas, por exemplo. Esta desorganização, na visão 
das docentes, também acaba culminando na não participação das famílias em momentos importantes do ano escolar: "Tem um distanciamento muito grande da família, até para entrega de avaliações. Existe todo trimestre uma taxa de infrequência, de avaliações acumuladas que os pais não vão retirar. A gente fica tentando agendar, mas estes pais não vêm" (J.).

A docente J.R. acrescenta: "a gente lida com comunidades muito difíceis, de famílias envolvidas com drogas, com tráfico... e chamar estas famílias para a escola é complicado, muito complicado".

Outras professoras, no entanto, apontaram experiências diferentes com famílias de nível socioeconômico menos favorecido e não acreditam que é a questão econômica que define a maior ou menor participação dos pais na escola. Para J. R. a experiência de ter lecionado em um município com marcada população economicamente desfavorecida da região metropolitana de Porto Alegre, foi bastante enriquecedora nesse sentido:

"A experiência de atender dois municípios, G. e Porto Alegre... G. são filhos de trabalhadores das fábricas de lá, e são famílias assim de classe bem baixa, renda bem baixa, mas são famílias que se parecem com as famílias de antigamente! São famílias que estão presentes, apesar de terem muitas dificuldades financeiras eles estão presentes ali...".

Ressaltou, ainda, que a participação dos pais atingia aproximadamente $98 \%$ nas reuniões e que isso era reflexo do valor que eles davam a educação dos seus filhos, pelo fato de entenderem que a educação é que poderia levá-los a um futuro melhor.

Foi também apontado por elas que é possível perceber claramente quando um aluno provém de uma família "estruturada ou não". Disseram que isso se reflete no comportamento, atitude e boas maneiras do aluno na escola: "Eles dizem 'com licença professora', 'bom dia', sabe... é diferenciado...” (M.A).

\section{Tema 2: Expectativas}

O entendimento das docentes sobre o conceito de família estruturada ou desestruturada acaba refletido nas expectativas, sejam elas positivas ou negativas, que tem no contato com as famílias de seus alunos. 


\subsection{Expectativas Negativas}

Algumas docentes associaram à renda e ao nível socioeconômico o fato de a família ser "desestruturada" e não seguir os modelos convencionais, conforme relata E.: "pelo menos na minha opinião, especialmente nas famílias de baixa renda, há uma desvalorização grande do núcleo familiar...é algo que se perdeu muito". Em outros casos, as docentes revelam uma descrença na participação de determinadas famílias na vida escolar de seus filhos, tendo em vista suas condições sócioeconomico-culturais: "tem determinados grupos de crianças que não adianta nada chamar a família... a mãe é louca e drogada, ou toma medicação, tem problemas psiquiátricos seríssimos, daquelas que tu não acredita... tu está falando com a mãe e ela batendo no rosto da criança" (J.). Assim, parecem existir famílias com as quais as docentes não conseguem lidar, pois possuem condições diferentes de vida ou estão envolvidas em situações problemáticas que extrapolam a vida escolar das crianças. As condições das famílias parecem determinar, assim, a maior ou menor disponibilidade das docentes em contatá-las, pois entendem que a presença das mesmas na escola pode, muitas vezes, acabar interferindo negativamente na rotina escolar. Além disso, as docentes definem seu nível de expectativa sobre tais núcleos familiares como parceiros educativos.

\subsection{Expectativas Positivas}

Existe, na opinião das docentes, um consenso de que famílias assíduas em participação na vida dos filhos fazem muita diferença em seu rendimento acadêmico:

"Tu vê direitinho aquele aluno que tem a complementação... é totalmente diferente. Muda completamente! Aquele aluno que tira 5 e a família está presente, realmente presente na vida do aluno, ele vai atrás... se a família tiver dinheiro para pagar aula particular ou não, ele vai chegar no professor e dizer 'professor tu me consegue um reforço?' E a escola dará o reforço sem receber nada, o aluno irá aos laboratórios [...]”.

Segundo J. também o fato de a família estar acompanhando de perto seu filho faz muita diferença, pois a criança passa a ter mais responsabilidade: "quando alguém deposita em ti uma expectativa, tu tem alguma coisa para alcançar".

Surgiu também um debate sobre a influência do aspecto socioeconômico na participação das famílias e no desempenho dos alunos. Algumas docentes 
apontaram que ser proveniente de uma condição socioeconômica menos favorecida não necessariamente significa menos interesse das famílias e envolvimento com a vida escolar dos filhos. Atribuem, entretanto, o envolvimento a aspectos de ordem emocional do funcionamento e da configuração familiar:

Eles...(referindo-se a famílias de renda baixa com as quais trabalha) estão sempre presentes, apesar das dificuldades financeiras. [...] Tu vê a diferença de como estas crianças chegam à escola... é a questão da estrutura mesmo, do pai. Lá a presença em reuniões é de que $100 \%$ dos pais". (J.R.).

\section{Tema 3: Demandas}

O tema Demandas diz respeito a todos os aspectos que derivam das famílias dos alunos e chegam à escola, mais especificamente à sala de aula e às professoras, com as quais elas sentem-se obrigadas a lidar. Na exploração dessa temática no grupo focal, foi possível perceber que as demandas são várias, mas principalmente a demanda por limites, ou seja, as famílias ora querem e validam os limites dados pela escola, ora contestam-nos. Também chegam a essas docentes demandas atemporais infantis, na tentativa de perpetuar um estágio de dependência dos alunos/filhos. Um aspecto fortemente debatido foi o assunto do clientelismo e a imposição dos pais para que suas vontades e exigências prevaleçam no ambiente escolar, utilizando instrumentos para isso, como o Estatuto da Criança e do Adolescente (ECA) e a Lei No 7.853, de 24 de Outubro de 1989 (designada aqui pelo termo Lei da Inclusão), de forma quase coercitiva.

\subsection{Limites}

O primeiro conteúdo que surgiu na discussão do grupo remeteu aos limites. As docentes salientaram que, por parte da família, há duas vertentes opostas: uma que solicita e valida os limites que a escola impõe aos seus filhos e outra que não aceita e vai contra qualquer tentativa da escola de impor algum tipo de limite aos seus filhos. Nesse sentido, alguns pais querem e pedem às professoras que assumam tal tarefa, posto que, muitas vezes, eles próprios não conseguem fazêlo: "tem famílias que só faltam se ajoelhar na tua frente e dizer 'obrigada! Tu deu limites ao meu filho [...] era isso que ele estava precisando"” (J.). Entretanto, há também aqueles que vão de encontro aos limites impostos, achando que a professora está sendo muito rigorosa, e acabam boicotando as combinações que as crianças estabelecem no espaço escolar, por não concordarem com elas. 
Algumas participantes mencionaram que, em algumas escolas particulares, o tema dos limites é tratado sempre de forma a atender aos desejos dos pais. Dessa forma, quando algum pai se sente descontente com alguma conduta de imposição de limites por parte da escola, basta ir até a direção da escola e determinar o que quer que seja feito.

Como diz J.R,

"a experiência que eu tenho em escola particular é bem diferente [...] era aquela coisa, os pais impunham o que deveria ser feito ou não dentro da escola. A criança tinha direito de fazer o que queria e, se tivesse qualquer tipo de limite, alguma coisa assim, que a criança sentisse, os pais iriam cobrar, cobrar da direção... a família determinava como a escola tinha que agir. A criança estava aprontando todas e chamavam os pais, mas, na verdade, ficava tudo assim 'abafa o caso', 'não vamos falar sobre isso', 'muda de assunto'....'.

Nessas ocasiões, a conduta dos pais era de desautorizar a escola.

Em muitos casos, por outro lado, os pais acabam transferindo às professoras atitudes que seriam de sua responsabilidade, como se a Escola fosse apenas uma extensão da casa da família. A principal alegação dos pais é, segundo as docentes, a falta de tempo que têm para educar e lidar com as necessidades de seus filhos, conforme aponta M.: "Os pais deixam tudo para a escola e dizem 'é que não tenho tido tempo', ou 'cheguei tarde, trabalhei o dia todo', ou 'tenho faculdade e chego sempre tarde". A professora C. P. ressalta que há demandas de aspectos básicos de limites e combinações, como ajudar a criança a se organizar para fazer o tema ou a dormir mais cedo, entre outras:

"Chegam a pedir coisas muito básicas... 'Olha, eu não tô conseguindo que a fulaninha se organize na hora do tema... dá uma faladinha com ela?' Ou, tipo, 'está difícil para deitar de noite, a coisa vai indo, vai indo, e quando vê já são onze horas e daí, é claro, não dá tempo de fazer o tema né, profe?'... daí vem bilhete na agenda: 'não fez o tema porque deitou muito tarde'. Pô! Como assim? Como é que a gente vai fazer isso? Essa alçada não é da escola, não é do professor".

A professora J. complementa, observando que em reuniões de pais na sua escola, muitos reclamam que o colégio não está trabalhando os hábitos de estudo e de organização, pois em casa eles não se organizam. "Tá, mas uma organização 
aqui nós temos! [...] mas em casa cada família vai ter a sua organização! Eu não tenho como dizer que o fulaninho vai estudar das 9 da noite às 10 . Isso é uma coisa que a família vai dizer!”.

\subsection{Demandas Imaturas}

Surgiu no grupo um debate sobre a existência de demandas da família que são consideradas por elas como infantis ou imaturas, mesmo quando os alunos atingem o Ensino Médio. Segundo as participantes, os pais chegam a solicitar às professoras que amarrem os cadarços dos tênis dos filhos ou que peçam aos colegas deles materiais ou favores que os seus filhos precisam, mas não têm coragem de pedir por serem muito tímidos. Acaba, assim, sendo uma demanda dos pais de que o professor faça coisas pelos alunos, perpetuando a dependência como forma de relação, seja no Ensino Fundamental ou no Médio. Conforme C. relata: É trabalhoso para a família, é trabalhoso deixar seu filho crescer, sabe? Gente, é incrível... Eu não imaginava que aqueles adolescentões lá, de Ensino Médio, que ficam namorando no pátio, tem aquela relação com o professor, fossem... pessoas tão infantis...".

\subsection{Clientelismo}

As professoras revelaram que há famílias as quais sentem que podem impor suas vontades à Instituição Escolar a qualquer custo, por perceberem que tem respaldo por parte desta em função da necessidade empresarial da escola pela permanência do aluno/filho. Elas nomearam esse fenômeno de "clientelismo", o qual se revela na atitude da escola em recuar frente a determinadas demandas de alguns pais, as quais nem sempre são próprias e, em ocasiões, desrespeitam as combinações e normas da instituição. A Escola, por sua vez, não quer perder o cliente e, nessas ocasiões, prepondera a visão de empresa. Esse fenômeno não ficou restrito a escolas privadas, onde muitas demandas dos pais acabam atendidas em função do desejo de que mantenham a criança matriculada. Nas escolas públicas, também aparece sob a característica de ameaças dos pais aos professores, onde os primeiros desejam ter suas demandas atendidas da forma que mais lhes convém, caso contrário, acabam forjando denúncias aos conselhos tutelares ou, até mesmo, delegacias de polícia.

As participantes mostraram-se preocupadas, assim, com a utilização do ECA (Estatuto da Criança e do Adolescente) como instrumento de ameaça por parte 
das famílias aos professores. Citaram casos de colegas que foram denunciadas na Delegacia de Polícia por pais que alegavam fatos descritos por elas como absurdos. A participante C. comenta tais casos:

"Houve outro caso que a professora foi punida porque deu uma bronca na menina na frente de todo mundo e ainda teve um outro que não me lembro exatamente o motivo. Gente! Essas pessoas foram para a Delegacia! O caso foi parar em várias instâncias e elas foram condenadas a pagar cestas básicas por um tempo. Imagina! Profissionais de anos, respeitadas... E isso não parou! Em nenhum momento se analisou quem é essa família que está fazendo isso? E tudo baseado em artigos do ECA. No final elas conseguiram bons advogados e ganharam a causa, mas antes disso, passaram por situações muito constrangedoras".

A professora J.R., que leciona em escola pública, relatou que o ECA tem sido usado como fonte de ameaça aos professores. Assim, quando os pais não têm suas vontades atendidas pela escola, porque a direção dá respaldo aos professores, acabam indo a outras instâncias: "os pais vão à SEC (Secreta ria da Educação e Cultura) fazer denúncias dos professores" (C.M.). As docentes acreditam que as crianças são orientadas em alguns programas sociais a usarem o Estatuto como ameaça. "Não se pode falar mais nada!", relatou C. As professoras também ficaram muito mobilizadas com o relato de J.R. :

"na escola que eu trabalho à tarde, surgiu uma coisa assim que... agora que a direção e o pessoal da supervisão e orientação estão começando a se dar conta... que as crianças estão se deixando roxas, fazem sucção da pele para ficar roxo e acusar os professores... (de maus tratos)". (J.R.).

A professora salientou, ainda, que lidam com comunidades muito difíceis, de famílias envolvidas com drogas, com tráfico e, portanto, chamar essas famílias para a escola é bastante complicado. Assim, tenta-se resolver tudo dentro da escola e as crianças, ao saberem disso e sabendo que a professora vai ser chamada para discutir qualquer situação na direção, acabam usando destes métodos para criar denúncias fictícias. Também, em muitas ocasiões, as crianças acabam chamando a atenção dos professores em sala de aula dizendo "não pode isso, não pode aquilo", ressaltando que sabem que está tudo no ECA. Para E. "há um problema de muitos direitos! Todo mundo tem muitos direitos". 
Vinculado a essa temática, encontra-se o tema da inclusão. As professoras referiram que determinados pais, munidos de diagnósticos, laudos, pareceres, comparecem às escolas fazendo exigências aos professores. Querem avaliações diferenciadas, troca de turma, trabalhos especiais, ou seja, querem estabelecer como os professores devem agir embasados na Lei da Inclusão. Há, portanto, uma exacerbação e distorção daquilo que são realmente necessidades educativas especiais dos alunos, por parte das famílias. Elucidando tal aspecto, C. comenta:

"A escola não está preparada para questões de inclusão, a gente vai recebendo os casos, se adaptando e vai resolvendo. E... vários! [...] Diagnósticos de Déficit de Atenção para todo o mundo, e as famílias vindo dizer 'não, olha, minha filha não está aprendendo porque a turma conversa, porque minha filha tem Déficit de Atenção'. Estão pedindo instrumentos de avaliação diferenciados para cada um, para cada caso! Médicos dando laudos, 'segundo o CID-10 tem diagnóstico tal e necessita de uma avaliação diferenciada'. Os professores têm que fazer vários instrumentos, várias provas e aí vem 'ai, mas eu não quero que os colegas percebam que a minha filha tá fazendo uma prova diferente, não quero que saia da sala de aula'...".

Estes aspectos relacionados à inclusão são mais prementes ainda na segunda etapa do Ensino Fundamental, de $5^{\mathrm{a}}$ a $8^{\mathrm{a}}$ séries, pois não há unidocência. Sendo assim, os professores não têm o mesmo período de tempo com os alunos, o que dificulta o trabalho mais individualizado com o aluno que tem dificuldades. Assim, estes profissionais acabam sendo mais cobrados pelos pais no que tange à atenção a este tipo de aluno.

Essas cobranças exacerbadas e, de certa forma, invasivas na tarefa do professor são vistas como decorrentes do clientelismo, ou da forma como os pais encaram sua relação de clientes com as escolas dos seus filhos, como se tivessem que ser atendidos em todas as suas necessidades e desejos sem se submeter à organização escolar.

\section{Mães}

As informações do grupo de pais foram tratadas e organizadas também em temas, os quais passam a ser apresentados a seguir, e que tratam especificamente da relação que as famílias estabelecem com a Escola dos seus filhos e da maneira como se envolvem na rotina escolar. Escolheu-se, na apresentação dos resultados e discussão, 
designar tal grupo por Mães, ao invés de Pais, em função da presença única de mães no encontro proposto para o grupo focal. Estas participantes refletiram sobre a forma como percebem a comunicação nos contatos com os professores e equipe pedagógica. Também foram debatidos o déficit que elas entendem existir nesta relação.

\section{Envolvimento com a Escola}

As mães participantes referiram ser bastante envolvidas com as escolas dos seus filhos das mais diversas formas. A participante P., por exemplo, relata que tanto ela como o marido sempre participaram da vida escolar das filhas, respeitando as idades: “... a minha filha de 14 a gente se despedia logo na entrada e ela sumia. E eu também não ficava procurando! E a pequeninha não, ainda tinha essa graça, levava até a hora da fila...". Além do envolvimento nas atividades escolares das filhas, P., segundo ela, por ser psicóloga, também acaba observando as relações entre os funcionários, preocupa-se com a rotina da escola e quer contribuir com os monitores quando percebe alguma situação que necessite de intervenção:

"Aviso o monitor que fica no pátio quando eu vejo alguma coisa... "olha lá, dá uma olhadinha que eles estão brigando". Então eu sou assim. Tanto eu como meu marido... lá junto! Na entrada e na saída. Então daí a gente vê bastante coisas, né? E a partir daí tu vai formulando, vai pensando e quando precisa coloca na agendinha 'marcar conversa com a professora'. Sempre! Três vezes ao ano no mínimo, de cada uma das meninas... então a gente está sempre participando, monitorando, acompanhando. Essa seria nossa rotina com a escola...”.

A participante C. refere que tem livre acesso na escola de seus filhos, que vê os coordenadores e o diretor caminhando pelos corredores junto com os alunos e sabe que frente a qualquer problema pode contar com a ajuda deles. Não sente receio em falar com as pessoas da equipe e, se precisar, marca horário com a professora ou vice-versa. Sente-se feliz com a relação de acessibilidade entre escola e família.

Já a participante D. passou por dificuldades na primeira escola que escolheu para o seu filho e acabou trocando-o de escola Em princípio não queria uma escola muito grande para que ele não sentisse tanta diferença da sua escola de educação infantil. Seguiu uma indicação dada pela psicóloga desta escola infantil e acabou decepcionando-se, pois não encontrou o que procurava: 
"era uma escola muito simples, muito humilde, particular, mas sem acesso nenhum, sem convivência familiar... era perto de onde eu morava, então assim... foi uma escolha muito horrível. Aí, através do clube que a gente frequenta, conhecendo mães, eu vi que podia ser diferente... porque eu sempre busquei na escola as relações sociais, familiares... para dar continuidade... que a escola não fosse só o lugar para ele estudar e sim de fazer amigos, conhecer os pais dos colegas e de buscar a convivência...”.

A partir de uma amiga do clube e de um informativo sobre a escola, D. resolveu visitar esta escola com o filho e o marido, que ficaram empolgados e efetivaram a troca: "É uma escola realmente muito familiar, com uma relação muito acessível, que a gente, a qualquer momento, conversa, através da agenda ou pessoalmente, inclusive, na fila, na chegada!".

A participante A.M. relata que por ser professora sente que a escola é seu lugar e isso está diretamente relacionado ao fato de sentir-se bem neste espaço - seja na escola onde trabalha ou na escola onde o filho estuda. Quando acha importante e necessário procura a instituição sem dificuldades, mas percebe que a relação família-escola passa por modificações a partir do $5^{\circ}$ ano: "eu sei que de $5^{\circ}$ em diante, guardadas algumas diferenças, é tudo meio parecido. $\mathrm{O}$ acesso dos pais, o relacionamento dos professores... porque aí muda o tipo de professor... é o professor mais especialista, não tem a visão geral que um professor de $1^{\mathrm{a}} \mathrm{a} 4^{\mathrm{a}}$ tem". A participante A. mencionou que sua relação com a escola da filha sempre foi muito tranquila, por ter sempre acreditado na instituição que escolheu. Sua relação com os professores é boa e caso a filha apresente alguma dificuldade ela tenta sempre resolver inicialmente com a menina, não pensa que a "culpa" é do professor. Sua forma de participação é diferente da de D.C., e ela ressalta que, embora não sendo da Associação de Pais, procura frequentar todas as reuniões e palestras para as quais é convidada:

"lá a gente tem encontros também... eu nunca participei de Associações de Pais e Mestres nem nada, mas tem reuniões a cada dois, três meses onde os pais são convidados, sempre colocando assim um psicólogo falando alguma coisa... eu vou..., enfim, eu acho muito boa a relação que a gente tem na escola".

A participante E., que estudou em escolas públicas e tem duas filhas que frequentam escolas estaduais, refere que sempre manteve boa relação com a escola 
das filhas. É uma escola pequena, de bairro, onde todos os alunos se conhecem porque moram próximos. Refere que a relação com os professores e com a equipe diretiva também é tranquila e nunca enfrentou problemas mais sérios. Relata que ela e o marido procuram ser participativos não apenas na escola, mas na vida, no dia a dia das filhas.

\section{Comunicação}

A comunicação foi um aspecto amplamente debatido entre as participantes do grupo, pois sentem que esta é escassa, ineficaz ou pouco elucidativa em diferentes situações. Ressaltaram, em primeiro plano, a dificuldade em falar com os professores e coordenadores sobre a avaliação de seus filhos. Muitas entendem que há falta de flexibilidade por parte da escola para discutir a avaliação e o rendimento escolar dos filhos. Assim, precisam marcar hora com o professor regente da turma, para que este, então, acesse o professor específico almejado. Quando conseguem falar com o professor diretamente, em muitas ocasiões, a fala institucional prepondera e o professor tem o mesmo discurso do diretor, do coordenador, do regente e nenhum consegue resolver e compreender as dúvidas dos pais. Nas palavras de P: "se tu quer falar com o professor de matemática, marcamos! Só que a conversa é a mesma. E eu cheguei a dizer 'vocês parecem que funcionam com um manual!'. E a vice-diretora achou aquilo o máximo e disse 'mas que bom! Este é o nosso objetivo'!".

As participantes usaram, então, o termo "robô", para se referirem às atitudes dos diferentes integrantes da escola ao se comunicarem com as famílias. Na avaliação das participantes, esses sujeitos têm um padrão de atendimento, considerado pela instituição como padrão de qualidade, como, por exemplo, no caso da adoção de um discurso único e na forma burocratizada de atenção às demandas familiares. Entretanto, para as famílias esse padrão de qualidade é percebido como distanciamento e não envolvimento real com o problema do qual querem conversar. A comunicação, desde essa perspectiva, é ineficaz, segundo a opinião das participantes.

A participante P. mencionou que ao lado da flexibilidade, que tanto escola como família devem ter a fim de estabelecer uma boa relação, deve estar a boa comunicação. Ela mencionou ter tido problemas na escola anterior das filhas em função de não ter conseguido se comunicar, já que a escola parecia ter adotado o mesmo discurso em todos os níveis - dos professores à equipe diretiva. Ressaltou que a comunicação 
deve ser uma construção de ambos os lados: "Então eu diria assim que junto com a palavra "flexibilidade" de ambos os lados, colocar também a palavra "comunicação" para isso e acho importante uma construção de ambos os lados e não só da escola pronta, preparada, de manual...”. As demais mães concordaram, pontuando que a escola também precisa estar aberta para ouvir os pais.

Portanto, um dos fatores que parece incomodar bastante as mães participantes é a forma como a escola está organizada para atendê-las. Muitas mencionaram que até o $4^{\circ}$ ano, onde ainda existe a unidocência, havia o acesso direto à professora para conversar, esclarecer dúvidas, trocar ideias. Quando as crianças chegaram ao $5^{\circ}$ ano, a comunicação com qualquer um dos professores passou a ser mediada pelo regente da turma, uma espécie de representante dos professores. Sendo assim, apenas nos momentos de entrega de avaliação é que os demais professores estão disponíveis para atender aos pais, mas nesses momentos é quase impossível acessar qualquer um deles. Como diz A.M.:

"Tu não chega mais em nenhum outro professor, a não ser na entrega de avaliação. Só que a entrega de avaliações é assim... é cada matéria numa sala... e aí tu vai lá... bom, português e matemática a fila é gigantesca.! E é assim... se é das 18:30 às $20: 30 \mathrm{hs}$, tu fala com duas ou três, porque tu não consegue conversar com mais ninguém, as filas são grandes. Só que é o único momento que tu tens para conversar com o professor diretamente, senão sempre é via regente. Eu acho complicado isso! Eu sei que os professores têm cargas horárias, têm toda uma questão burocrática... mas quando eu quero falar com o professor de matemática não adianta eu dizer as coisas para a professora de artes, que é a regente! Ela tem ali, ela trouxe algumas anotações... mas ela mesmo chega a te dizer 'é, comigo ele é diferente'. Bom, né! Então fica difícil a gente conversar”.

A falta de acesso aos professores específicos das diferentes matérias, portanto, deixa muitas mães insatisfeitas. Por outro lado, em algumas outras escolas, outras mães referiram que os professores atendem aos pais, desde que marquem hora.

Outro aspecto que elucida também a comunicação padronizada é a forma como os professores, ou coordenadores se dirigem a elas, chamando-as apenas de "mãe" e não pelo nome. Parece, assim, que todas as mães são iguais em suas dúvidas e 
necessidades e que a escola está em um patamar diferenciado, tendo que ensinar e dar instruções às famílias. $\mathrm{O}$ fato de não serem chamadas pelo nome as deixa irritadas, pois distancia a relação com o interlocutor, no caso, o professor.

Observa-se que o grupo não tem prioritariamente uma vivência de acesso direto aos professores de seus filhos a partir da troca da unidocência à pluridocência $\mathrm{e}$ este aspecto gera um distanciamento da família da vida escolar. Nesses casos, a relação passa a ser mais superficial e ocasional.

Outro aspecto da comunicação, debatido no grupo, refere-se às informações pouco claras que vêm da escola com relação às exigências e responsabilidades próprias de cada ano letivo. Algumas participantes se mostram mais apreensivas com as maiores responsabilidades e exigências que vão surgindo conforme os filhos vão passando de ano. Temem que eles não deem conta do volume de trabalhos, semana de provas e temas de casa. Nesse caso, as mães pesquisadas revelaram sentirem-se pouco preparadas para acompanhar as mudanças inerentes à estrutura acadêmica, tal como a passagem da unidocência para a pluridocência. Além do mais, sentem-se pouco informadas pelas escolas a respeito de como funciona o sistema avaliativo, quais são os objetivos, as responsabilidades que os filhos terão de assumir e como a família pode ajudar nessa etapa de transição. Sem compreender de forma correta tais mudanças, os pais passam a ficar angustiados e a questionar a escola e os professores em busca de respostas.

Muitas vezes, as dificuldades dos filhos com a matéria acabam mobilizando toda família, que precisa se reorganizar para auxiliar à criança. Na ânsia de ver os filhos vencerem as dificuldades, os pais contratam professores particulares ou separam um tempo para estudar com os filhos. Como menciona D. :

"[...] daí usam a agenda, eles marcam as provas, todo o conteúdo das provas está listado na agenda.... Até o ano passado não era assim... eram os pareceres, eram avaliações. Agora é prova é numero... O último semestre vale o dobro, eles tem que buscar nota mais alta no ultimo trimestre que eles estão mais cansados... Levei isso para reunião de pais, que eu acho assim muito errado, muito difícil. E eles disseram que não, porque lá eles já vão estar preparados, já vão ter passado pelo processo do primeiro e do segundo trimestre e no último eles vão estar mais fortes... e eu achando que, no último, eles estariam mais cansados. Então, 
aos poucos, eu fui mudando meu jeito... eu estava arrancando os cabelos! Contratei professora particular, sentava junto para estudar e disse 'meu Deus, ele não vai dar conta' e os professores diziam 'vão, eles vão dar conta'. Bom... deu conta, passou por média e eu chorando... eles realmente conseguem”.

\section{Dificuldades Percebidas na Relação Família-Escola}

As participantes discutiram sobre quais seriam, na sua visão, os maiores impedimentos na boa relação da famílias com a escola. Além de mencionarem o descaso de determinadas família, as participantes referiram que falta flexibilidade tanto por parte da escola quanto da família para que a parceria seja melhor e não haja uma desmotivação. "Eu acho que falta nessa parceria escola-família que os pais sejam flexíveis, estejam preparados para ouvir o lado de lá, e que a escola seja flexível e esteja preparada para ouvir o lado de cá...”. (D.).

Assim, frente a alguma dificuldade, entendem que os pais não devem simplesmente trocar o filho de escola, mas sim ouvir da escola o que está acontecendo, pois todas as escolas terão aspectos bons e ruins e o que vai diferenciar uma boa parceria é a base familiar e o acompanhamento da família. Como menciona A.:

"todas as escolas têm coisas muito boas e coisas muito ruins... TODAS! Não é diferente... e vai muito daquilo que é a base familiar, do que tu passa, do interesse que os pais têm em acompanhar a vida dos filhos!". A participante D.C. complementa: "Por que quem é que faz a escola? É a família! Não interessa se é lá dentro ou lá da vila (...), se todas as famílias tiverem a mesma conversa, não vai ter problema nenhum dentro daquela escola, gente! Não vai! Não sei se eu estou certa... mas parece assim ó 'eu não sei mais educar, então tu professora que se vire!’ Não é assim”.

Percebe-se, assim, que por mais que digam que a flexibilidade deve ocorrer de ambos os lados, estas participantes parecem responsabilizar e atribuir maior peso às atitudes de descaso dos pais e das famílias nas dificuldades que existem na relação escola-família. Por outro lado, algumas mães reforçaram que existem exemplos de mães bastante participativas que não tiveram respaldo positivo da escola, e todas concordam que estas são minoria, casos isolados. 


\section{Mercantilização da Educação}

As participantes referem exigências sobrepassadas, tendo em vista a necessidade de os alunos serem aprovados em exames qualificativos após os anos escolares. Nesse caso, a escola empenha-se na aprovação dos alunos nestes exames, em detrimento dos aspectos emocionais dos mesmos.

A participante A.M. discorda das metodologias utilizadas na avaliação dos alunos. Pensa que, em alguns momentos, não há um limite para as exigências que se fazem às crianças e às famílias e isto se deve ao fato de as escolas quererem atingir notas $\mathrm{e}$ índices cada vez mais altos na classificação do ENEM e outras provas implementadas pelo Ministério da Educação e Cultura (MEC). Assim, exigem dos alunos sem estarem preocupadas com sua aprendizagem real, pois o mais importante é a nota final classificatória nos Exames Nacionais que aparecerá na mídia e que poderá trazer novos alunos à escola, revertendo em lucros financeiros diretos ou indiretos. Esta mentalidade empresarial é vista por elas como "mercantilização do ensino". No entanto, algumas participantes também apontaram que muitos pais buscam exatamente estas exigências da escola, pois ao escolherem a instituição de ensino onde colocaram seus filhos levaram em conta o ensino exigente que culminaria na aprovação em exames preparatórios e no exame vestibular.

Ainda assim, quando as participantes percebem que os filhos estão sendo preparados para ter um bom desempenho em uma prova avaliativa, que contará para a valorização e maior divulgação da escola, se incomodam, pois pensam que, nestes momentos, não se leva em consideração as necessidades dos seus filhos e nem suas eventuais dificuldades. Percebem, portanto, o ensino mais voltado a atender às demandas da escola do que a dos alunos nas suas particularidades.

Entendem, portanto, que a Educação não deve ser vista como uma mercadoria. O fato de se estabelecer entre as escolas privadas e as famílias uma relação como a de prestadores de serviço e clientes dificulta a boa comunicação entre estas instituições. Isso gera consequências também na qualidade da educação dos alunos, conforme menciona A.:

"Tem escolas particulares que nem reprovam... eles vão dando chances, tipo 'vamos fazer mais uma prova', mais uma chance..., porque pensam que se rodar o pai vai tirar de lá... aí vai do despreparo dos pais também, que já vem com aquela história antiga de 'ah não tá bem meu filho, vou trocar!'. Isso é fugir do problema!". 


\section{Discussão}

A análise das diferentes perspectivas sobre a relação que se estabelece entre a família e a escola, revelou uma complexa articulação entre diversos aspectos e temáticas que transpassam e formatam, de alguma maneira, a interação que se estabelece entre as duas instituições. Mais do que descrever uma dicotomia no exercício de diferentes papéis, conforme passou a ser definida a partir de meados do século XX (VILA, 2003; HILL e TAYLOR, 2004), as informações coletadas nos grupos investigados remetem a uma realidade perfilada por fronteiras difusas entre a família e a escola, revelando temáticas conflitivas e, por vezes, dificuldades que obstruem essa relação. Considerando as evidências da importância da parceria entre a família e a escola como fator preditor do desenvolvimento saudável de crianças e jovens (CAVALCANTE, 1998; BHERING; SIRAJ-BLATCHFORD, 1999; XU, 2002; POLONIA; DESSEN, 2005, KOUTROUBA et al., 2009; EPSTEIN, 2011), pode-se constatar, a partir das informações dos participantes, que esse é ainda um tema que, apesar de essencial, tem sido tratado por ambas instituições envolvidas de forma estereotipada e reativa às circunstâncias de cada contexto. Sentiu-se falta de uma reflexão mais aprofundada tanto por parte dos familiares como dos professores na compreensão do fenômeno. A família e a escola, na fala dos participantes, aparecem em lados opostos, num jogo de culpabilidades mútuas, atribuições equivocadas e simplificadas dos episódios com que lidam no seu cotidiano frente à tarefa de educar.

Nessa perspectiva, tanto as mães entrevistadas como as professoras, têm uma crítica bastante aguçada, enfatizando os aspectos negativos, muitas vezes em detrimento dos positivos, na interação que estabelecem, no caso, a família com a escola e a escola com a família. Mais especificamente, a caracterização das famílias feita pelas professoras descreve, eminentemente, problemáticas relativas à estrutura e ao funcionamento dos núcleos que reverberam na pratica docente e no espaço escolar. Somado a isso, a ideia de que há famílias muito difíceis e que justamente essas são aquelas que não participam e "não gostam" da escola, reforça o isolamento de tais núcleos, fazendo que com que estes, por descrição, necessitados de apoio e atenção, fiquem ainda mais desamparados pela escola. Por outro lado, são atribuídos àqueles núcleos familiares que cumprem as expectativas desejadas no que se refere aos critérios de estrutura e configuração, os méritos do êxito de seus filhos. Nesse sentido há uma evidente simplificação da explicação do fenômeno, isso é, se há fracasso, a família é a responsável, se há sucesso, também. 
Os docentes reconhecem a importância da expectativa da família sobre os filhos no seu desenvolvimento escolar. Entretanto, não conseguem dar-se conta da reverberação das suas expectativas frente às famílias de seus alunos. Em definitivo, a relação família-escola é um processo que se retroalimenta, isso é, mais e melhores expectativas podem gerar mais e melhores respostas. Nesse caso, as professoras revelam uma atitude de descrédito frente a determinadas famílias, carregada de pré-concepções, o que, muitas vezes, enfraquece uma relação potencialmente promissora.

Partindo da crença que aparece, tanto nas falas das professoras como das mães investigadas, de que o desempenho do aluno é resultante da dinâmica familiar que ele vivencia, a família é considerada como a grande responsável pelo sucesso ou a única culpada pelo fracasso escolar de seu filho (OLIVEIRA; MARINHO-ARAUJO, 2010, CARVALHO, 2000). Frente a essa realidade que tem regulado tal relação, parecenos que seria necessário trabalhar o corpo docente na compreensão sistêmica desse fenômeno, identificando os aspectos que, a partir das expectativas, se retroalimentam e perpetuam as dificuldades na aproximação da família com a escola, independente das suas características de configuração e estrutura.

Nessa perspectiva, as demandas reveladas pelos professores que chegam desde as famílias de seus alunos são das mais diversas ordens. Por outro lado, as mães também declaram o quanto esperam da escola em termos de que seus filhos sejam bem atendidos, que haja boa comunicação, que o ambiente escolar seja de abertura, entre tantas outras necessidades difíceis de serem atendidas. Frente a tão complexas demandas, família e escola parecem ter compreensões distintas. A família parece esperar que a escola seja capaz de suprir as mais diversas necessidades de seus filhos e a escola, por sua vez, considera as famílias pouco competentes no exercício de seu papel e, por isso, pensam que derivam à escola. Frente a isso, perguntamos: Há verdadeiramente uma falha no exercício da educação familiar ou as expectativas dos pais quanto ao que a escola possa dar e ensinar a seus filhos estão sobrevalorizadas? Talvez um de nossos desafios seja o de redimensionar tais expectativas a fim de superar o jogo de culpabilidades que tem permeado essa relação.

Pode-se perceber que a maximização da função educativa da escola aparece naquilo que foi nomeado de clientelismo. Isso é, a escola aparece como o lugar onde tudo deve funcionar a fim de atender as demandas e expectativas das famílias e, se isso 
não ocorrer, aparecem estratégias coercitivas de ordem econômica, moral e ética a fim de manter a escola nesse lugar: o de atender as expectativas e favorecer o desenvolvimento pleno das crianças e jovens. Provavelmente, essa dinâmica que caracteriza atualmente as relações entre a família e a escola esteja baseada em concepções educativas equivocadas que confundem excelência com benevolência.

Nessa perspectiva, revelam-se algumas incoerências no discurso das mães que falam de suas angústias frente às cobranças de desempenho de seus filhos, mencionando, inclusive, uma relação mercantilista que a escola estabelece com o filho/aluno visando à sua aprovação em exames nacionais, tais como o ENEM, sem que o foco seja a educação integral do sujeito. Entretanto, esse mesmo grupo também revela uma preocupação específica com o resultado do filho na escola, isso é, que ele de conta dos conteúdos, que passe de ano, que seja classificado, referindo muita ansiedade no acompanhamento desse processo. Assim, observase que as mães têm teorias de como a escola deveria funcionar, entretanto, na prática, quando se referem a seus filhos e suas experiências, essas teorias não são as que balizam suas atitudes educativas.

Tais contradições, não invalidam o envolvimento das mães participantes na vida escolar de seus filhos, embora cada uma participe da rotina escolar e se envolva de diferentes maneiras. Algumas frequentam as reuniões de pais, outras valorizam a possibilidade de ter livre acesso à equipe, outras acompanham o dia a dia escolar mais de perto, outras exercem atividades voluntárias para contribuir com a instituição e participar da rotina, etc. Ainda assim, considerando o depoimento dos professores investigados, nem sempre a forma de participação que as mães estão dispostas a exercer vai ao encontro daquilo que a escola espera. As docentes reclamam da escassa participação dos pais em reuniões e entregas de boletins, que são os momentos em que a escola se disponibiliza e está aberta para receber os pais. As mães, por sua vez, reclamam de falta de acesso aos professores quando necessitam conversar com eles, tendo que aguardar apenas o dia da entrega de avaliações, ficando assim definido oficialmente que o desempenho do aluno seria o elo de ligação mais importante que mereceria o encontro da família com a escola.

A comunicação família-escola, assim, é ponto fundamental de discussão, na medida em que o discurso da escola parece ser sempre o de chamar a atenção dos pais para que deixem seus filhos crescer, mas não há proposição de estratégias que possam informá-los no intuito de ajudá-los 
a entender os procedimentos e processos escolares (como a avaliação, por exemplo) e, também, a saberem como podem ajudar seus filhos em casa, minimizando suas ansiedades. Estudo realizado por Ditrano e Silverstein (2006) apontou que os pais querem, na verdade, poder conhecer o dia a dia da escola e da sala de aula e, para tal, precisam de instruções claras sobre a organização da mesma, para saberem como e com o quê podem colaborar. Desejam, portanto, diálogo mais aberto com os professores e maior acesso à informação para que não se sintam alheios e passivos ante ao processo de aprendizagem de seus filhos, da mesma forma que foi apontado pelas mães participantes do grupo focal. Fica evidente que a confiança na interação da família com a escola é um aspecto essencial e que define as relações, independente dos currículos escolares.

Frente a isso, faz-se importante mencionar que, devido à metodologia de trabalho utilizada nessa investigação, contou-se com a participação voluntária das famílias, que aqui foram representadas somente pelas mães, sem a presença de nenhum pai. Por outro lado, as professoras que se voluntariaram, também demonstraram um diferencial de quem está envolvido com a tarefa educativa a ponto de disponibilizar-se para discuti-la assim como refletir sobre sua prática cotidiana. Nesse sentido, a especificidade dos participantes da pesquisa é uma das limitações desse estudo, que não corrobora a maioria da população. Entretanto, além das várias reflexões que as informações nos proporcionaram, concluímos que a tarefa educativa é composta de contradições, erros, acertos, desejos e atitudes, muitas vezes contraditórios e enviesados, mas que expressam um compromisso, em maior ou menor grau, daqueles que, por definição, se encontram envolvidos ao longo desse exercício: a família e a escola. Sendo assim, todo o investimento que venha a favorecer o encontro de pais e educadores no desenvolvimento de uma efetiva parceria frente à tarefa educativa, será bem vindo.

Nesta perspectiva, é possível pensar que tais contradições, queixas, culpabilizações, delegações de responsabilidades e frustrações nas relações entre docentes e famílias não irão desparecer per se. É necessário que cada instituição, de acordo com suas características e condições, faça um esforço para sistematizar estratégias conjuntas que contemplem docentes e pais em suas reivindicações a fim de desenvolver a tarefa educativa de forma mais plena, satisfatória e eficaz. 


\section{Referências}

BHERING, E.; SIRAJ-BLATCHFORD, I. A relação Escola-Pais: um modelo de trocas e colaboração. Cadernos de Pesquisa, São Paulo, n. 106, p. 191-216, mar. 1999.

BHERING, E.; DE NEZ, T. B. Envolvimento de pais em creche: possibilidades e dificuldades de parceria. Psicologia: Teoria e Pesquisa, v. 1, n. 18, p. 63-73, jan./abr. 2002.

CARVALHO, M. E. P. de. Relações entre Família e Escola e suas implicações de Gênero. Cadernos de Pesquisa, São Paulo, n. 110, p. 143-155, jul. 2000.

. Modos de Educação, Gênero e Relações Escola-Família. Cadernos de Pesquisa, São Paulo, v. 34, n. 121, p. 41-58, jan./abr. 2004.

CAVALCANTE, R. S. C. Colaboração entre pais e escola: educação abrangente. Psicologia Escolar e Educacional, Campinas, v. 2, n. 2, p. 153$160,1998$.

DITRANO, C. J.; SILVERSTEIN, L. B. Listening to parents' voices: participatory action research in the schools. Professional Psychology: research and practice, [S.1.], v. 4, n. 37, p. 359-366, ago. 2006.

EPSTEIN, J. L. School, Family, and Community Partnerships: preparing educators and improving schools. Johns Hopkins University: Westview Press, 2011.

GARBÓ, M. J. C. Quién reprueba realmente, la escuela o la familia? Revista Educarnos, [S. 1.], v. 2, n. 8, p. 11-35, mar. 2013.

GONDIN, S. M. G. Grupos Focais como Técnica de Investigação Qualitativa: Desafios Metodológicos. Paidéia, Ribeirão Preto, v. 12 n. 24, p. 149-161, 2003.

GUTIÉRREZ, J.; DELGADO, J. M. Métodos y Técnicas Cualitativas de Investigación en Ciencias Sociales. Madrid: Síntesis, 1995.

HILL, N. E.; TAYLOR, L. C. Parental school involvement and children's academic achievement. Current Directions in Psychological Science, [S.1.], v. 13, n. 4, p. 161-164, ago. 2004. 
KOUTROUBA, K. et al. An investigation of greek teachers' views on Parental Involvement in Education. School Psychology International, v. 30, n. 3, p. 311-328, jun. 2009.

LEWIS, A. E.; FORMAN, T. A. Contestation or Collaboration? A Comparative Study of Home-School Relations. Anthropology\& Education Quarterly, [S.1.], v. 33, n. 1, p. 60-89, mar. 2002.

MORGAN, D. L. Focus group as qualitative research. Newbury Park: Sage Publication, 1988. (Qualitative Research Methods Series 16).

OLABUÉNAGA, J. I. R. Metodologia de lainvestigación cualitativa. Bilbao: Universidad de Deusto, 1999.

OLIVEIRA, C. B. E.; MARINHO-ARAÚJO, C. M. A relação família-escola: intersecções e desafios. Estudos de Psicologia, Campinas, v. 27, n. 1, p. 99108, jan./mar. 2010.

POLONIA, A. da C.; DESSEN, M. A. Em busca de uma compreensão das Relações entre Família e Escola. Psicologia Escolar e Educacional, [S.1.], v. 9, n. 2, p. 303-312, 2005.

RIBEIRO, D. F.; ANDRADE, A. dos S. A Assimetria na Relação entre Família e Escola Pública. Paidéia, Ribeirão Preto, v. 16, n. 35, p. 385-394, jan. 2006.

SANDERS, M. G.; EPSTEIN, J. L.; CONNORS-TADROS, L. Family Partnerships with High Schools: the parents' perspective. Baltimore: Johns Hopkins University; Center for Research on the Education of Students Placed at Risk, 1999. (Report n. 32).

SILVEIRA, L. M. O. B. A Relação Família-Escola: uma parceria possível? In.: WAGNER, A. et al. Desafios Psicossociais da Família Contemporânea: pesquisas e reflexões. Porto Alegre: Artmed, 2011. p. 181-190.

VILA, I. Familia y escuela: dos contextos y un solo niño. In.: ALFONSO, C. et al. La participación de los padres y madres en la escuela. Barcelona: Editorial GRÀO, 2003. p. 27-38. 
VILLAS-BOAS, M. A. A Relação Escola-Família-Comunidade inserida na problemática da formação de professores. [S. 1.: s. n., s.d]. Disponível em: $<$ http://www.educ.fc.ul.pt/recentes/mpfip/pdfs/adelinavillasboas.pdf $\geq$. Acesso em: 03 dez. 2011.

VYVERMAN, V.; VETTENBURG, N. Parent Participation at School: a research study on the perspectives of children. Child.-Glob. J. Child Res., v. 1, n. 16, p. 105-123, fev. 2009.

WAGNER, A.; SARRIERA, J. C.; CASAS, F. Os Direitos da Infância: a perspectiva das crianças, seus pais e professores. Porto Alegre: Nova Prova Editora, 2009.

WAGNER, A.; TRONCO, C.; ARMANI, A. B. Introdução: os desafios da família contemporânea: revisitando conceitos. In: WAGNER, A. et al. Desafios Psicossociais da Família Contemporânea: pesquisas e reflexões. Porto Alegre: Artmed, 2011. p. 19-35.

XU, J. Do early adolescents want family involvement in their education? Hearing voices from those who matter most. The School Community Journal, [S.1.], v. 12, p. 53-72, 2002.

Recebido em: 01/04/2013

Aceito para publicação em: 04/09/2013

\section{Family-school relationship from the perspective of teachers and parents of children attending primary school \\ Abstract}

Although the benefits of a close relationship between families and school have been already proved, it appears that there still are many obstacles to be transposed in order to make this relationship more effective. The school seems to have difficulties in understanding the reality experienced by their students and families, and the asymmetry in this relationship tends to perpetuate the difficulties of building an effective partnership that encourages student involvement in the academic space. Facing this reality, the objective of this paper is to present the 
school and family perspectives on the peculiarities of this relationship from the testimony of Parents and Teachers of Elementary School kids. Two focus groups were conducted: one with Elementary School Teachers (ten participants) and one with Parents of students (seven participants) attending the same stage of schooling. By content analysis, the information collected from the groups were categorized. The Teachers'group configured the following topics: Demands of families that appear on teaching practice; Situations that require interaction with families; Teachers' perception about families and their roles. Analysis of the Parents' group resulted in the following themes: Family involvement with their children's school; Communication with the school; Perceived difficulties in family-school relationship, Commodification of Education. The conclusions refer to a reality shaped by diffuse boundaries between family and school, revealing difficulties that obstruct this relationship and converge to a set of mutual guiltiness. It is also discussed the possibility of optimizing this relationship through systematic joint strategies that address Teachers and Parents in their claims. From this perspective, it is highlighted the importance of developing the educational task together, always having the student in focus and as a priority in this process.

Keywords: Family-School Relationship. Elementary School. Education.

\section{La relación familia-escuela bajo la óptica de profesores y padres de niños de la Educación General Básica \\ Resumen}

Aunque ya están comprobados los beneficios de la proximidad entre Familia y Escuela, se observa que existen muchos obstáculos todavía para que esta relación sea eficaz. Parece que la escuela tiene dificultades para entender la realidad que los alumnos y familias viven y la asimetría de tal relación tiende a perpetuar las dificultades en la construcción de una alianza eficaz que favorezca la integración del alumno en el espacio académico. Frente a esta realidad, nuestro objetivo es presentar la perspectiva de la escuela y de la familia sobre las vicisitudes de esa relación a partir de las informaciones de padres y profesores de la Educación General Básica. Se realizaron dos grupos focales: uno con profesores de la Enseñanza Básica (10 participantes) y otro con los padres de alumnos (7 participantes) que comparten la misma etapa de escolarización. A partir del Análisis de Contenido, las informaciones del grupo focal con los docentes configuraron los siguientes temas: Demandas de las familias que aparecen en 
la práctica docente; Situaciones que demandan interacción con las familias; Percepción del profesor sobre la familia y sobre su papel. Del análisis del grupo de padres surgieron los siguientes temas: Aproximación de la familia con la escuela de sus hijos; La comunicación con la escuela; Dificultades observadas en la Relación Familia-Escuela; Mercantilización de la Educación. Las conclusiones remiten a una realidad diagramada por fronteras difusas entre familia y escuela, revelando dificultades que obstruyen esa relación y que confluyen hacia un juego de culpabilidades mutuas. Se discute la posibilidad de optimizar dicha relación a partir de estrategias conjuntas sistemáticas que contemplen tanto a los docentes como a los padres en sus reivindicaciones. Desde esta perspectiva se retoma la importancia de desarrollar la tarea educativa de manera conjunta, teniendo siempre al alumno como foco y prioridad de ese proceso.

Palabras claves: Relación Familia-Escuela. Enseñanza Básica. Educación. 